\title{
Herbert Sukopp - an inspiring pioneer in the field of urban ecology
}

\author{
Ingo Kowarik ${ }^{1,2}$
}

Published online: 24 March 2020

(C) The Author(s) 2020

\begin{abstract}
Urban ecology is a well-established integrative discipline with many historical roots. One of the eminent pioneers of urban ecology is the German ecologist Herbert Sukopp, who works in Berlin since the late 1950s and is often referred to as the founder of the "Berlin School of Urban Ecology". On the occasion of his 90th anniversary in 2020, this paper aims to recognize and commemorate the major contributions of Sukopp to the field of urban ecology, based on his scientific work and on results of an online survey on his perception in the international scientific community. Sukopp's contributions were groundbreaking for the establishment of urban ecology. Specifically, his work furthered: (1) the performance of comprehensive biodiversity studies across all land-use types within the city, in relation to the specifics of urban environments; (2) the establishment of modern approaches of nature conservation in cities and their integration into all land-use types, and the city as a whole; (3) the formation of a multidisciplinary conceptual basis of urban ecology as a modern science, with combined scientific and applied perspectives, ultimately aiming at the preservation and further development of nature within cities for the benefit of urban residents. Herbert Sukopp is thus an important and inspiring pioneer in the field of urban ecology.
\end{abstract}

Keywords Urban ecology $\cdot$ History $\cdot$ Biodiversity conservation in cities $\cdot$ Conceptual approaches

\section{Introduction}

Urban ecology has gained tremendous significance - in a century during which half of humanity lived in cities and urbanization was recognized as a major driver of environmental change globally (Grimm et al. 2008; Ellis 2015). Urban ecology was established as a science in the 1970s, with historical roots in various disciplines (Sukopp 2002; Marzluff et al. 2008; Douglas et al. 2010; McDonnell 2011; Wu 2014), leading ultimately to integrative approaches towards understanding cities as coupled social-ecological systems that necessitate transdisciplinary research approaches (Alberti et al. 2003; McPhearson et al. 2016). One of the pioneers of urban ecology is the German ecologist Herbert Sukopp (Fig. 1), who has worked since 1959 at the Technische Universität Berlin, and for the most part at the Institute

Ingo Kowarik

kowarik@tu-berlin.de

1 Department of Ecology, Ecosystem Science/Plant Ecology, Technische Universität Berlin, Rothenburgstr. 12, 1215 Berlin, Germany

2 Berlin-Brandenburg Institute of Advanced Biodiversity Research, Berlin, Germany of Ecology. His important role in the field, and in establishing the "Berlin School of Urban Ecology", is briefly acknowledged in many textbooks on urban ecology (e.g. Douglas et al. 2010; Forman 2014) as well as in many conceptual papers (recently McPhearson et al. 2016). The compilation of important former work in the field of urban ecology by Marzluff et al. (2008) also includes two papers of Sukopp.

Yet biases have hindered the full understanding and commemoration of Sukopp as an eminent scholar in the development of contemporary urban ecology. In particular, most of Sukopp's work is written in the German language - as well as earlier acknowledgements of his person as in the 'Festschrift' for his 65th birthday (Kowarik et al. 1995). Sukopp's perception by the international readership is thus likely biased by few easy accessible publications in English language some of which are cited in Table 1. International schools of urban ecology may consequently not fully recognize the contribution of Sukopp to the field. The important review by $\mathrm{Wu}$ (2014) highlights Sukopp's role as a pioneer in the "bio-ecological approach" in urban ecology. As is shown here, urban biodiversity is indeed an important part of Sukopp's work in last six decades. However, it was much broader in scope and included biodiversity analyses of all land use types in 


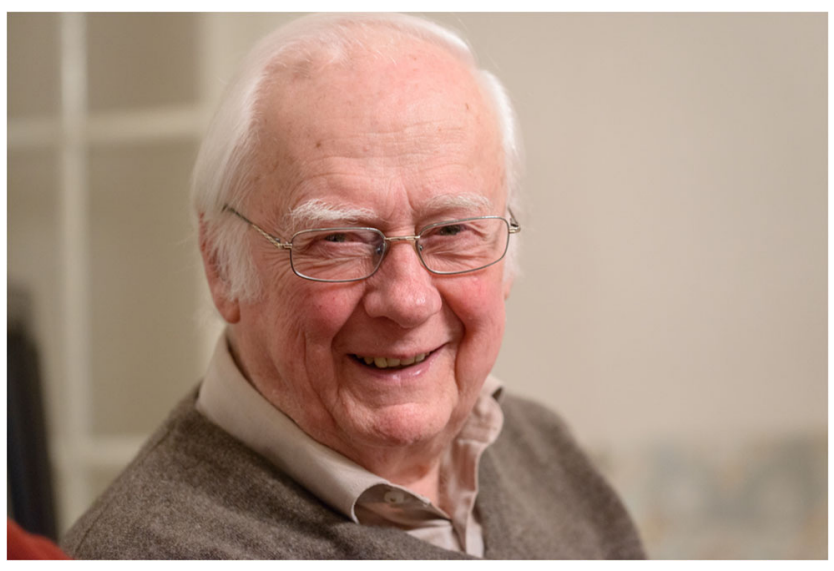

Fig. 1 Herbert Sukopp in 2016 (Foto: Axel Auhagen)

cities as well as novel conceptual approaches to nature conservation and urban ecology as a multidisciplinary field of science.

The 90th anniversary of Herbert Sukopp in 2020 is the perfect occasion to commemorate his contributions to the field of urban ecology, and to assess international perceptions of his contributions to urban ecology. This is done here by combining three approaches: (i) reporting some data on Sukopp's publications; (ii) analyzing results of an unpublished online survey from 2015 which intended to capture the perception of Sukopp's work by the international scientific community, and (iii) reflecting major contributions of Sukopp to different facets of urban ecology and the development of the scientific discipline. This is based on the personal knowledge of his work and my long-lasting co-operation with Herbert Sukopp - and supported by open comments of participants in the online survey.

\section{Online survey}

To provide more comprehensive insights into the perception of Sukopp's work by the scientific community, an online survey was conducted on the occasion of Sukopp's 85th birthday asking how urban ecologists around the world rate the importance of his work in regard to different facets of urban ecology. Participants were also asked which of his publications they would recommend, and to share personal comments. The survey was launched in 2015, using a self-administered online questionnaire. To include scholars from different fields of urban ecology and from many countries, invitations were distributed via supra-national scientific societies, including the Ecological Society of Germany, Austria and Switzerland and the Society for Urban Ecology (SURE). In addition, personal networks were used, and in both cases, the survey participants were encouraged to further distribute the invitation.

The survey yielded responses of 203 participants from 39 countries, including 55 respondents from Germany (27\%). Men were overrepresented with $63 \%$; almost half of respondents (46\%) were younger than 40 years; $41 \%$ fell into the age class of 40-60 years, and the remaining $13 \%$ were older than 60 years. The vast majority $(78 \%)$ declared not to have worked in Berlin at any time. Asked about their main interest in the field of urban ecology, the respondents mentioned the following areas: plants $(38 \%)$, planning issues $(24.4 \%)$, animals (18.3\%), social issues $(9.2 \%)$, other $(10.1 \%)$. Sixty-four respondents declared not to have heard of Herbert Sukopp in the context of urban ecology and consequently did not respond to the questions concerning his work. The following results thus rely on answers of 139 respondents. Of these, $43 \%$ remembered a personal contact to Herbert Sukopp, while 57\% stated never having met him or listened to one of his talks.

Given the enormous rise and specialization in urban ecology during the last decades, respondents of this survey likely do not represent the scientific community in its geographic and topical diversity. Participants from Germany and Europe, for example, are over-represented. Yet the provided personal background information suggests that the survey relies on a broad variety of respondents. Results of the survey are presented in Section 5.

\section{Biographical sketch}

The direction and priorities of scientific work are often closely linked to the biography of scientists. In Sukopp's case, a close relationship with Berlin, including family ties, was highly influential. His scientific career took place in the first decades after the Second World War, during which an unintentional succession experiment took place: the natural recolonization of many war-destroyed areas of Berlin. As a young botanist, Sukopp was highly impressed by the emergence of wild urban nature at the heart of Germany's largest city. Also important for the direction of his work were the orientation of the study programs in which he taught, and his voluntary commitment to nature conservation in Berlin.

Herbert Sukopp (Fig. 1) was born in Berlin, Germany, on 6 November 1930. He graduated from high school in Berlin in 1949, shortly after the end of the Second World War. He entered the Pädagogische Hochschule in Berlin in 1949 and qualified as a teacher in 1953. In the same year, Sukopp began his studies of botany, geology and sociology at the Freie Universität Berlin, ending with a doctorate in 1958. His thesis addressed the vegetation, and human-induced changes, of mires in Berlin (Sukopp 1959/1960). After a short intermezzo as research assistant (195759) at the Institute for Systematic Botany and Phytogeography at the Freie Universität Berlin, Sukopp started his work at the 
Table 1 Annotated list of the 15 most frequently cited publications by Herbert Sukopp (as from Google Scholar, 6 Jan 2020), translations of titles in German by IK. Publications recommended by respondents in a survey from 2015 (see details in the text) are indicated by symbols ( $\mathrm{x}=1-$ 3 , xx 4-8, xxx 9-24 recommendations).

\begin{tabular}{|c|c|c|c|}
\hline Publication & $\begin{array}{l}\text { Google } \\
\text { Scholar }\end{array}$ & $\begin{array}{l}\text { Sur- } \\
\text { vey }\end{array}$ & Annotation \\
\hline $\begin{array}{l}\text { Sukopp, H. (1972). Wandel von Flora und Vegetation in } \\
\text { Mitteleuropa unter dem Einfluß des Menschen } \\
\text { [Human-mediated changes of flora and vegetation in } \\
\text { Central Europe] }\end{array}$ & 275 & $\mathrm{XX}$ & $\begin{array}{l}\text { Comprehensive review on human impacts on flora and } \\
\text { vegetation, including a conceptual scheme on the hemeroby } \\
\text { approach, a measure of human impact }\end{array}$ \\
\hline $\begin{array}{l}\text { Zerbe, S., Maurer, U., Schmitz, S., \& Sukopp, H. (2003). } \\
\text { Biodiversity in Berlin and its potential for nature con- } \\
\text { servation }\end{array}$ & 275 & $\mathrm{X}$ & $\begin{array}{l}\text { Synthesis of results from two doctoral theses in combination } \\
\text { with general information on biodiversity patterns and their } \\
\text { relevance for biodiversity conservation in Berlin }\end{array}$ \\
\hline $\begin{array}{l}\text { Sukopp, H., Wittig, R. (eds.) (1993). Stadtökologie. [Urban } \\
\text { ecology; second edition 1998] }\end{array}$ & 260 & XXX & $\begin{array}{l}\text { First textbook on urban ecology that introduces multiple } \\
\text { perspectives of urban ecology, including the human } \\
\text { dimension, and defines urban ecology as an integrated field } \\
\text { of research of natural and social sciences, and planning with } \\
\text { the aim of improving living conditions and the sustainable } \\
\text { development of cities }\end{array}$ \\
\hline $\begin{array}{l}\text { Lohmeyer, W. \& Sukopp, H. (1992). Agriophyten in der } \\
\text { Vegetation Mitteleuropas [Agriophytes in the vegetation } \\
\text { of Central Europe] }\end{array}$ & 253 & $X$ & $\begin{array}{l}\text { Comprehensive synthesis on non-native plant species } \\
\text { established in near-natural vegetation types (i.e., } \\
\text { agriophytes) of Central Europe }\end{array}$ \\
\hline $\begin{array}{l}\text { Sukopp, H. (2002). On the early history of urban ecology in } \\
\text { Europe [reprint in Marzluff et al. 2008] }\end{array}$ & 237 & XXX & $\begin{array}{l}\text { Review of early (mainly European) urban biodiversity studies, } \\
\text { covering castles and ruins, parks and gardens, studies on } \\
\text { biological invasions in cities, post-war rubbles sites, other } \\
\text { habitats and cities as a whole }\end{array}$ \\
\hline $\begin{array}{l}\text { Korneck, D., \& Sukopp, H. (1988). Rote Liste der in der } \\
\text { Bundesrepublik Deutschland ausgestorbenen, } \\
\text { verschollenen und gefährdeten Farn-und Blütenpflanzen } \\
\text { und ihre Auswertung für den Arten-und Biotopschutz }\end{array}$ & 203 & & $\begin{array}{l}\text { Sukopp has implemented a first Red List for plants in Germany } \\
\text { (Sukopp 1974), which was updated several times since then. } \\
\text { This version from } 1988 \text { was influential as it uncovered } \\
\text { drivers of decline, many of which were linked to agriculture. }\end{array}$ \\
\hline
\end{tabular}

[Red List of the extinct, lost and endangered vascular plants in the Federal Republic of Germany and its evaluation for biodiversity conservation]

Sukopp, H. (1998). Urban ecology—scientific and practical aspects

Sukopp, H., \& Werner, P. (1983). Urban environments and vegetation

Sukopp, H. (1969). Der Einfluss des Menschen auf die Vegetation. [The human impact on vegetation]

Sukopp, H., \& Weiler, S. (1988). Biotope mapping and nature conservation strategies in urban areas of the Federal Republic of Germany

Sukopp, H. (2004). Human-caused impact on preserved vegetation

Sukopp, H., Hejný, S., Kowarik, I. (Eds.). (1990). Urban ecology: plants and plant communities in urban environments

Sukopp, H. (Ed.). (1990). Stadtökologie: das Beispiel Berlin. [Urban ecology: the case of Berlin]

Short synthesis, with a focus on urban biodiversity and the ecological differentiation of cities, including the historical perspective and some links to environmental policies.

Short synthesis with a focus on urban flora and vegetation

Conceptual paper on assessing the human influence on urban flora and vegetation, adopting the hemeroby approach to a central European city

Comprehensive synthesis on approaches of urban biotope mappings, their application in Germany, and significance for urban planning

Short overview of human-induced changes to urban habitats, and of gains and losses of species in cities

Edited book with chapters on urban plants and vegetation, mostly from European cities

Comprehensive synthesis on Berlin's natural landscape, of anthropogenic changes of climate, waters, flora, fauna and vegetation; in-depth analyses of a broad range of near-natural and anthropogenic land-use types from multiple ecological perspectives; main synthesis of the work done in Berlin until the late 1980s

Sukopp, H., Blume, H. P., \& Kunick, W. (1979). The soil, flora, and vegetation of Berlin's waste lands

Overview of work on soils, flora and vegetation of urban vacant land, with examples from Berlin

Sukopp, H., Numata, M., \& Huber, A. (Eds.). (1995). geographic stretch 
Technische Universität Berlin in 1959, initially as a research associate to Ulrich Berger-Landefeldt at the Institute for Applied Botany. Sukopp received his university teaching certificate (habilitation) in 1968 in the field of botany. One year later he became a professor, and in April 1971 a full professor and head of the Department of Ecosystem Science and Vegetation Ecology at the then newly founded Institute of Ecology at the Technische Universität Berlin. As an Emeritus professor since 1996, Sukopp continues his work today.

As an academic teacher, Sukopp was mainly involved in interdisciplinary study programs in the field of landscape planning, which included ecology, environmental planning and landscape architecture. Sukopp's main contributions to the curricula included courses on ecosystem science, vegetation science, urban ecology, and nature conservation. Together with colleagues, Sukopp also led field courses on urban sites that integrated approaches from vegetation science, animal ecology, soil science, urban climatology and hydrology as early as in the 1970s. For many students (myself included), it was fascinating how Sukopp explained the principles of succession on vacant land between thunderous traffic in downtown Berlin and also very knowledgeable and illustrative the history of the introduction and spread of the many non-native species involved in succession dynamics. Thus, many students learned early on that the Mediterranean wallrocket (Diplotaxis tenuifolia) can be recognized by its smell of roast pork and that native Mentha (mint) species can be distinguished by whether they smell like either English or US American chewing gum.

Sukopp supervised a broad number of diploma and doctoral theses, spanning different fields including:

- urban ecology, e.g. Kunick $(1974,1982)$ on the organization of plant assemblages along an urbanization gradient in Berlin;

- nature conservation, e.g. Auhagen (1985) on conservation approaches for humid forests threatened by drainage;

- invasion ecology, e.g. Trepl (1984) on the invasive Impatiens parviflora;

- vegetation science, e.g. Müller (1988) on lawns in Bavarian cities or Seidling (1990) on forest remnants.

In addition to his academic work, Sukopp has been the Berlin State Commissioner for Nature Conservation and Landscape Management for 25 years (1975-2000). In this honorable function, he advised public authorities in a broad range of environmental and conservation issues in Berlin. This work was connected with important feedback loops between Sukopp's scientific work and the challenges of environmental development in Berlin. That is why much of the work in the Sukopp group addressed timely environmental issues, and why the resulting scientific output notably supported the development of Berlin as a green city as shown in detail in books on Greening Berlin
(Lachmund 2013) and the intersection of urban ecology and landscape planning in Berlin (Pobloth 2008).

\section{Publications}

The work of Herbert Sukopp encompasses approximately 654 publications from 1955 to 2018 (Fig. 2). This body of work includes some edited books, a high number of book chapters, conference proceedings, journal papers, and other publications. Most of these are in German and not covered by data bases like the Web of Science that reports only 10 publications. Table 1 shows the 15 most often cited publications as from Google Scholar that largely address urban issues; a full publication list is available in Maubach (1995) and online at https://www.oekosys.tu-berlin.de/menue/ team/herbert_sukopp/.

\section{Contributions to the field of urban ecology}

The synthesis of respondents' answers in Fig. 3 indicates important contributions of Sukopp to different topics in urban ecology. These include the understanding of urban biodiversity patterns, the conceptual development of approaches towards urban biodiversity conversation and its implementation in the real world, syntheses of existing knowledge about urban ecology, and an engagement in capacity building and networking in the field of urban ecology in Germany and far beyond.

\subsection{Understanding urban biodiversity}

Sukopp's contributions to the field of urban biodiversity is most prominent in the answers of respondents. In comments, participants explained that Sukopp promoted "thinking city as a part of nature", demonstrated the "importance of vegetation" and analyzed "urban floras and the processes structuring them". One person mentioned that Sukopp had initialized the "study of flora and vegetation of urban parks and has integrated these fields into urban ecology". The contributions to the understanding of urban biodiversity might be due to a threefold engagement of Sukopp:

- First, he was personally engaged in field work to investigate the composition and classification of urban vegetation, in particular of different succession stages on vacant land (e.g. Kohler and Sukopp 1964, Sukopp 1971).

- Second, Sukopp supervised a wealth of biodiversity analyses of urban, agricultural and near-natural land-use types in Berlin (and some other cities), mostly in doctoral theses or research projects. 
Fig. 2 Number of publications by Herbert Sukopp in 1955-2018 (based on Maubach 1995 and more recent data at https://www. oekosys.tu-berlin.de/menue/team/ herbert_sukopp/)

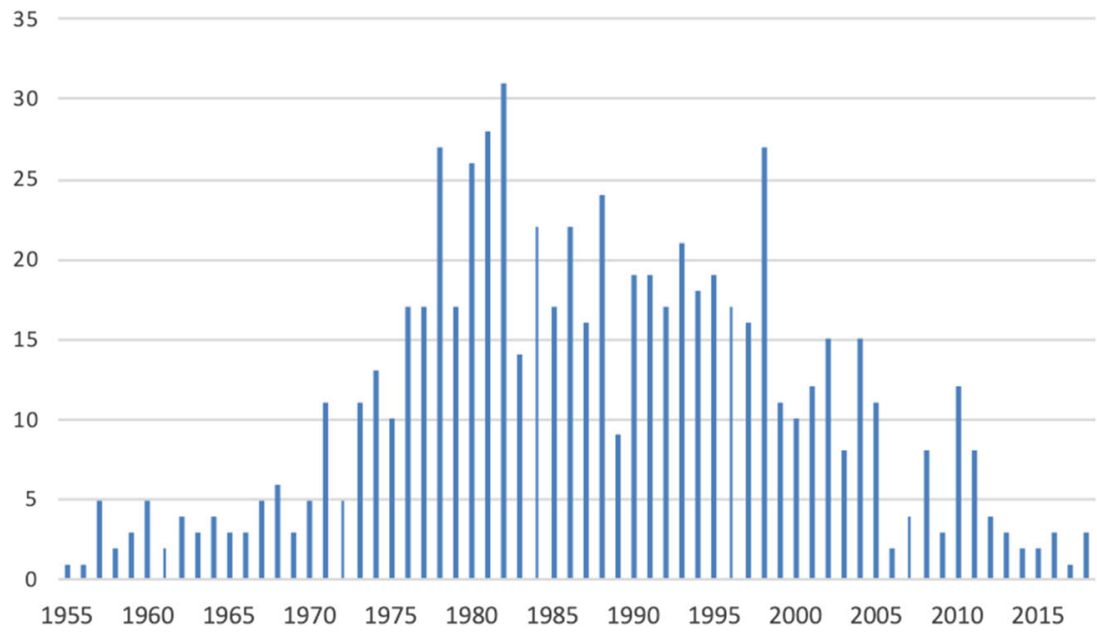

Examples cover nearly all land-use types within cities such as agricultural areas (Böcker 1978), forests (Auhagen 1985), cemeteries (Graf 1986), lawns (Müller 1988), streetscapes (Langer 1994), vacant land and industrial areas (Dettmar 1992), parks (Nath 1990; Peschel 2000), and differently aged residential areas (Maurer 2002; Röhricht 2003); and heterogeneous areas of the city as well (Böcker et al. 1985).

- Third, Sukopp and co-workers synthezised urban biodiversity studies from Berlin and other cities (e.g. Sukopp et al. 1979a, 1980; Sukopp and Werner 1983; Zerbe et al. 2003) and edited multi-author books on urban biodiversity (e.g. Sukopp 1990; Sukopp et al. 1990, 1995).

These activities have shown since the 1970s that all urban land use types can be characterized by different combinations of plant species and communities. The systems studied included a broad spectrum very early on, ranging from classic objects of ecological investigation such as near-natural forests or wetlands to specifically urban systems such as gardens and green spaces, whereby "uncomfortable" areas such as roadsides, vacant land or waste dumps were included early on.

Nevertheless, the work in Berlin went far beyond reporting biodiversity patterns as it early yielded important conceptual approaches towards the ecology of the city, and analyses of interdependencies between urban drivers and biodiversity patterns. Most importantly, Sukopp presented a conceptual spatial model of a city as early as in 1968 (as part of his habilitation thesis; first published in Sukopp 1973, slightly modified and reprinted numerous times, also in English language). This model postulates relationships between the urban form (housing density, impervious surface), urban climate, urban soils, hydrology and biodiversity patterns and implies a spatial urban rural-gradient. Comprehensive ecological
Fig. 3 Results of an online survey on the importance of Herbert Sukopp's work in regard to different topics in urban ecology, based on answers of 139 respondents

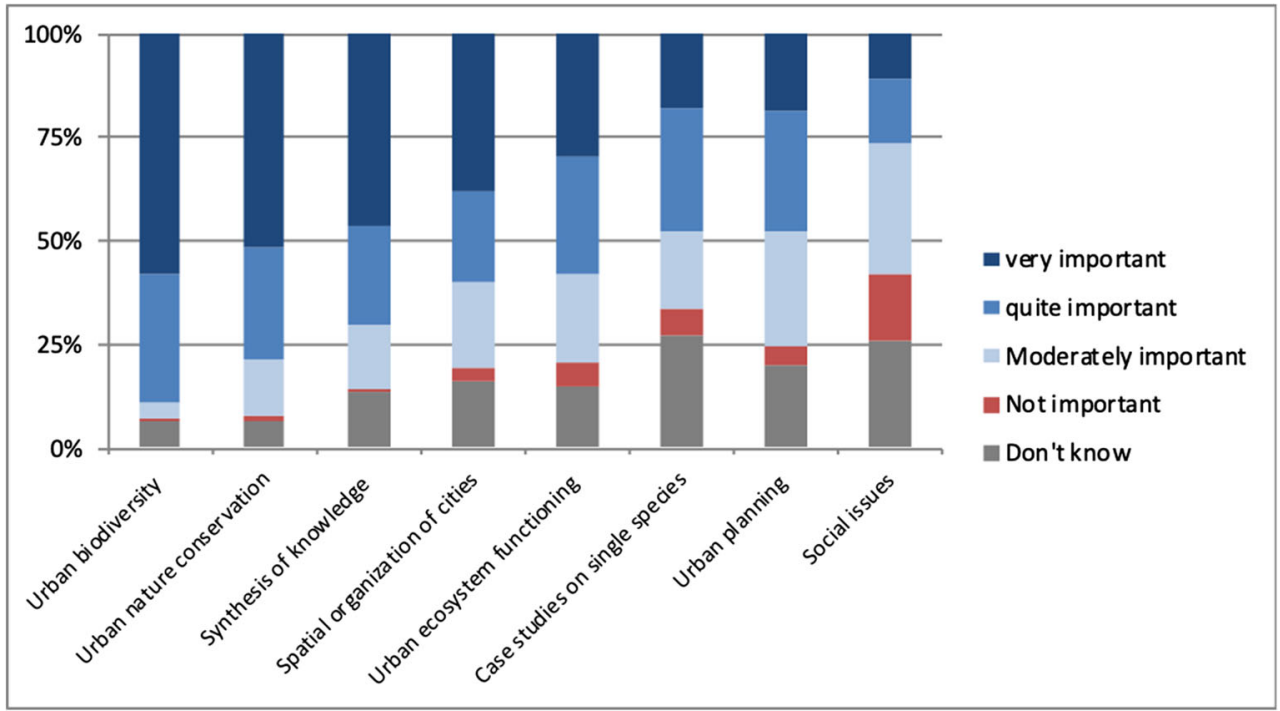


analyses of urban-rural gradients became an important topic in urban ecology later, in particular with work from New York (McDonnell and Pickett 1990). One of Sukopp's first PhD students, Wolfram Kunick (1974, 1982), analyzed relationships between the urban form and biodiversity patterns along an urban-rural gradient. Kunick did not explicitly use the term urban-rural gradient. Yet since he selected his study areas within the Berlin urban area mainly according to varying housing density, his work is a pioneering work of urban gradient analysis, where the gradient ranges from plots located in Berlin's compact urban core to forest plots in the urban fringe.

Many of Sukopp's research projects involved colleagues to analyze urban land-use types from multiple disciplinary perspectives and to reveal links between land use, diversity patterns, and soil and climate features (e.g. Böcker et al. 1985, Brande et al. 1990). This work in Berlin is synthesized in Sukopp et al. (1980), and in Sukopp (1990). While much of this pioneer research was descriptive, the multi-disciplinary approaches early linked urban biodiversity analyses with other components of urban ecosystems and helped setting the scene for later approaches aiming at a more mechanistic understanding of how biodiversity relates to other ecosystem components in cities.

How human agency influences biodiversity patterns has been early in Sukopp's research focus. His salient review on this issue (Sukopp 1972) was highly influential, at least in Germany, and introduced the hemeroby approach - a measure of human impact - of the Finnish botanist Jalas (1955) to a broader scientific community (Sukopp 1969, 1972), with novel links to soil science (e.g. Blume and Sukopp 1976). The hemeroby approach was later specified by another of Sukopp's PhD students and used to uncover patterns of native and non-native species in response to varying levels of human impact in Berlin (Kowarik 1988, 1990). Non-native plant species as an important facet of human-mediated changes to the flora and vegetation of cities have early attracted the scientific interest of Sukopp who highlighted these species as a significant feature of urban biodiversity in his ground-breaking work on "the city as a subject for ecological research" (Sukopp 1973/2008). Sukopp always also dedicated attention to the distribution or performance of single species in urban settings, spanning from early studies on Chenopodium [Dysphania] botrys (Sukopp 1971) to, most recently, Pterocarya fraxinifolia (Sukopp et al. 2015).

Beyond novel scientific insights into urban biodiversity patterns in relation to urban form and various human activities, the work performed or encouraged by Herbert Sukopp, as a whole, has raised awareness and acceptance of urban biodiversity (studies) at an early stage far beyond Berlin and Germany.

\subsection{Implementing approaches towards urban nature conservation}

As Sukopp's second most important contribution in the field of urban ecology, the respondents emphasized his role in the establishment of urban nature conservation (Fig. 3.) One respondent stated: "He was one of the first people, at least in Germany, who paid attention to urban habitats and who asked for a nature conservation approach also in urban areas with different focus than in the open landscape." Sukopp's contribution to the implementation of nature conservation in the urban realm was manifold and included the following:

- Early assessments of losses in plant species for the area of Berlin (Sukopp 1966), and analyses of humanmediated changes in vegetation (for mires: Sukopp 1959/60; for reed beds: Sukopp and Markstein 1989). These insights were used to establish first Red Lists for Berlin, likely the first for cities - as in 1979 for the flora of Berlin, and later on for a broad range of plant and animal taxa (Sukopp and Elvers 1982; Auhagen et al. 1991), including a recent Red List for plants which Sukopp co-authored (Seitz et al. 2018).

- Sukopp played a key role in establishing the instrument of comprehensive biotope mapping for urban areas. Such biotope maps illustrate the spatial organization of urban ecosystems and cities as a whole and make it possible to consider the entire range of urban land use types with regard to their habitat function and a range of ecosystem services. In parallel, biotope maps support urban planning by providing spatially explicit information on ecologically (and culturally) relevant structures (see Sukopp and Weiler 1988). From 1978 to 1996, Sukopp led a group working on methods for biotope mapping (Sukopp et al. 1979b; Schulte et al. 1993). As a consequence, hundreds of biotope mappings had been performed for settlements of various size in Germany and in other countries. Such maps are still an essential basis for urban biodiversity conservation (Qiu et al. 2010) and highly useful, for example, to assess the relative importance of biotope types for endangered species (e.g. Planchuelo et al. 2019).

- Sukopp and colleagues developed a framework of principles and objectives for nature conservation in cities, which early on combined traditional goals of biodiversity conservation with anthropocentric goals and what we now call ecosystem services. The first publication on this topic (Auhagen and Sukopp 1983) was further developed by various teams of authors. Importantly, these principles also underpinned Berlin's "Landscape Program including 
Species Protection Program", a key planning instrument that guides the conservation and development of open spaces in Berlin by integrating perspectives of biodiversity conservation, environmental protection, protection of the landscape scenery and support for recreation activities. Sukopp headed a large interdisciplinary working group that developed groundbreaking programmatic plans, general guidelines and detailed recommendations for the total surface of (then-West) Berlin, specified for a wealth of single and aggregated biotope types (AGA 1984). This work was likely unprecedented in its conceptual range and level of detail (Lachmund, 2013). Condensed and continuously revised versions of the Landscape Program have been adopted by the Berlin Parliament since 1988 and are today still leading the development of Green Berlin (Thierfelder and Kabisch 2016; Kowarik 2019).

Sukopp's work was highly influential in providing fundamental ecological information about urban nature across all land-use types within cities and their interplay with human agency. He also encouraged conservation approaches beyond the traditional focus on endangered species, by linking ecological with anthropocentric perspectives. This early let to the insight that the most important role of urban nature is in supporting manifold benefits for urban residents (Auhagen and Sukopp 1983). Historical analyses by Pobloth (2008) and Lachmund (2013) illustrate in much detail how approaches of Sukopp and his colleagues influenced urban planning in Berlin, supporting "Greening Berlin" as a "co-production of science, politics, and urban nature" (Lachmund 2013). In addition, Matthew Gandy's film from 2017, "Natura Urbana. The Brachen of Berlin", centers on activities of Herbert Sukopp and his co-workers, with several interview passages (Lawton et al. 2019). With innumerable talks and publications Sukopp popularized nature conservation in cities far beyond Berlin. In this vein, one participant in the survey stated that "His links with applied ecologist and managers like George Barker had a significant impact on urban wildlife conservation in the U.K.".

\subsection{Synthesis of knowledge}

One of Sukopp's great achievements is to bring together widely scattered scientific results, which is noteworthy as this was done at a time without access to digital publications or easily available photocopiers. I have seen many handwritten excerpts of works by Scandinavian authors that Sukopp brought back from trips to Sweden and Finland in the 1960s.
Examples of his synthesizing work include early reviews on the human impact on flora and vegetation (Sukopp 1969, 1972), on non-native species (Sukopp 1962; Lohmeyer and Sukopp 1992) and, importantly, his seminal work on "the city as a subject for ecological research" (Sukopp 1973); an English version of the latter is included in Marzluff et al. (2008). Here, Sukopp combined a review of the state of knowledge at that time with own conceptual approaches towards the spatial and ecological characterization of cities. This approach guided the scientific work in Berlin and paved the way for integrative approaches in urban ecology. Correspondingly, syntheses of the work in Berlin characterize the total range of urban land-use types, or biotopes, from multiple ecological disciplines (Sukopp et al. 1990; Sukopp 1990). Moreover, Sukopp was always interested in the historical roots of his discipline. He synthesized knowledge "On the early history of urban ecology in Europe" (Sukopp 2002/ 2008) and on the history of geobotanical research in Berlin (Krausch and Sukopp 2010).

A range of books on urban ecosystems or biodiversity existed before (e.g. Stearns and Montag 1975; Laurie 1979; Boyden et al. 1981; Bornkamm et al. 1982; Klausnitzer 1987; Gilbert 1989; see review by McDonnell 2011). Still, Sukopp's book on "Urban Ecology" from 1993 is often being addressed as the first textbook in urban ecology that introduces a broad multidisciplinary perspective. This book written in German was edited together with Rüdiger Wittig (Sukopp and Wittig 1993, second edition 1998) and combined chapters from multiple disciplinary perspectives, such as from human geography, population dynamics, human health, psychology, urban climate, soils and hydrology, waters, fauna, flora and vegetation, urban metabolism, ecological structure of cities and urban habitats, ecological planning, and finally, economics of ecological urban development.

In the introduction to this textbook, Sukopp and Wittig (1993, p. 2) highlighted as major aim of urban ecology "not primarily to clarify ecosystem interrelationships, but to explore ways to make the urban ecosystem as human-friendly as possible". That's why they conclude that "the natural science disciplines are not sufficient for the ecological research of the city, because the city represents a product of human society, whose investigation therefore also falls into the field of social sciences". In the second edition Sukopp and Wittig (1998, p. 2) consequently define the science of urban ecology as a combination of two perspectives:

- "Urban ecology in the narrower sense is the subdiscipline of ecology that investigates urban biocoenoses, biotopes and ecosystems, their organisms and site conditions as well as the structure, function and history of urban ecosystems.

- Urban ecology in a broader sense is an integrated field of research of several sciences from different areas and planning with the aim of improving 
living conditions and sustainable environmental urban development." [translation by the author]

This conceptual approach thus integrated humans into studies of urban ecosystems by addressing humans as drivers of, and respondents to urban ecosystems, and as targets for developing livable cities. Sukopp and Wittig's definition clearly anticipates modern definitions of urban ecology such as the following: "Urban ecology integrates both basic (i.e. fundamental) and applied (i.e. problem oriented), natural and social science research to explore and elucidate the multiple dimensions of urban ecosystems." (McDonnell 2011).

Many important conceptual works on urban ecology attribute Sukopp's work (and the Berlin School in general) to a "bio-ecological" approach (Wu 2014) or to the "ecology in cities" (McPhearson et al. 2016). The latter is "classic urban ecology focusing on primary ecological questions in urban areas, such as how ecological patterns and processes in cities compare with those in other environments and how urbanization and development affect the ecology of organisms in urban habitats" (McPhearson et al. 2016). Pickett et al. (2016) highlight that ecology of the city "extends analysis to built and infrastructural patches" which has been early done in Berlin, including studies on effects of management or other human interferences. Indeed, understanding urban biodiversity patterns was highly important in many Berlin studies. Yet, the range of issues covered by Sukopp's work, and ultimately the interdisciplinary approach of the Sukopp and Wittig textbook from 1993/98, indicates that his contribution to the field is broader. He early connected approaches of urban biodiversity studies with the human dimension, generally in urban ecology, and particularly in urban nature conservation. Albeit not in the center of his activities, Sukopp's work also includes some early links to the "ecology of cities" as a systems science that "integrates multiple disciplinary approaches — such as ecology and sociology - along with transdisciplinary perspectives ...to study the city as a complex, highly interactive, social ecosystem" (McPhearson et al. 2016).

Correspondingly, many participants in the survey emphasized the textbook book from 1993/1998, in combination with the previously mentioned work, as highly important in "founding of urban ecology as a scientific discipline" and providing "a conceptual basis of urban ecology". Sukopp is thus one of the fathers of modern urban ecology.

\subsection{Capacity building and networking}

Respondents also highlighted the role of Sukopp in capacity building:" He influenced and brought up a whole generation of urban ecologists" and "inspired students and young colleagues". Indeed, Sukopp supervised more than 130 diploma theses and about 32 doctoral theses. Some of his students became professors; many work in public administrations in the field of landscape planning and nature conservation - in Berlin and across Germany - or in related planning consultancies. Sukopp's influence, however, went far beyond his own students, as participants in the study described. "The publications and presentations of Herbert Sukopp convinced me to start studying urban ecology". Another participant said: "I became aware of Prof. Sukopp's work when I was working on my PhD in the 1980's. Exposure to his work and his connections to other urban ecologists in Europe shaped me as a young ecologist and continues to influence my work". Another respondent summarized: "His work has been a major source of inspiration for (at the time) young researchers, at least in Europe. In this way, he has played a major role in the establishment of the field of Urban Ecology in other European countries.

Networking was also an important part of Sukopp's activities. He invested much time in travelling (mostly in Europe, but also in Japan and China), giving innumerous talks at conferences and a broad range of stakeholder meetings. He inspired or led a range of working groups in Berlin, Germany and beyond, and worked in many commissions, including the UNESCO MAB Urban Ecology Group. Sukopp was also in contact with other pioneers in the field of urban ecology, such as Forest Stearns, George Barker, and Makoto Numata. With the latter he has also edited conference proceedings (Sukopp et al. 1995). It is particularly noteworthy that during the Cold War Sukopp also maintained contacts with many scientists in East Germany and other states in the Russian sphere of influence. In this way he also contributed to the establishment of urban ecology research in Russia (Kavtaradze 1995). Similarly, Wu et al. (2014) reported that "Herbert Sukopp's visit to China in 1988 presumably promoted the adoption of the "ecology in city" approach in China". After the fall of the Berlin Wall in 1989, many colleagues from the former Russian sphere of influence came to Berlin, and some worked for a short time in the Institute of Ecology like Ladislav Mucina and Michael Succow.

All these activities together facilitated, as one participant said, "awareness raising of the importance of urban ecology as a science and policy field". As one result, the field of urban ecology became quite popular in Europe as early as in the 1980s. While Sukopp's activities centered mostly in Europe, the influence of his work beyond is likely more indirect. In this vein, one participant stated: "Links to US-American (LTER) and other foreign 'urban ecologies' would be interesting, also the perhaps underestimated influence of Prof. Sukopp on these international approaches".

Ultimately, the personality of Herbert Sukopp, which combines great professional competence with friendliness, attentiveness and modesty, has certainly also contributed to the broad acceptance of his work. On the occasion of Sukopp's 65 th birthday the then senator for urban development Volker Hassemer explained the important influence of Sukopp in 
Berlin also with the combination of competence and friendliness in his person (Hassemer 1995). One respondent summarized Sukopp's influence as follows: "Urban ecology is born out of Herbert's curiosity, profound observations and university-based, multi-disciplinary research .... After the birth of the eco-city baby, many milk brothers and sisters grew up on different continents. Many of us were visiting Berlin's ecourban kindergarten, with careful instruction by Herbert and Inge Sukopp's hospitality ... Urban ecology is growing up and passed the period of science puberty, so Prof H. Sukopp seems to be soon (or already) multi-grandfather of many of us. Urban ecology is face-to-face contact science."

\section{Conclusions}

Today, urban ecology is a well-established multi-disciplinary and integrative scientific discipline of great relevance to the development of future cities (McDonnell and Hahs 2013; Wu et al. 2014; McPherason et al. 2016). Studies on urban biodiversity are booming (Shwartz et al. 2014). The integration of biodiversity in urban development (Aronson et al. 2017; Nilon et al. 2017; Parris et al. 2018), as well as the integration of humans in urban ecology (Alberti et al. 2003; McPhearson et al. 2016; Pickett et al. 2016), represent timely issues. While modern urban ecology has many origins, important roots go back to Herbert Sukopp and the Berlin School of Urban Ecology, which he founded in the 1970s. Sukopp's contributions were groundbreaking for the establishment of urban ecology particularly in regard to (1) the performance of comprehensive biodiversity studies across all land-use types within the city, in relation to the specifics of urban environments; (2) the establishment of modern approaches of nature conservation in cities and their integration into all land-use types, and the city as a whole; (3) important contributions to the establishment of a multidisciplinary conceptual basis of urban ecology as a modern science, with combined scientific and applied perspectives, ultimately aiming at the preservation and further development of nature within cities for the benefit of urban residents. Herbert Sukopp is thus an important and inspiring pioneer in the field.

\begin{abstract}
Acknowledgements My first thanks go to Herbert Sukopp for many inspirations, which strongly influenced the direction of my scientific development very early on. I would also like to thank Glenn Guntenspergen, Charlie Nilon and Monika Egerer as well as two anonymous reviewers for very helpful comments and Daniel Brinkmeyer for the technical implementation of the online survey. Tanja Straka and Monika Egerer have kindly improved my English.
\end{abstract}

Funding Information Open Access funding provided by Projekt DEAL.

Open Access This article is licensed under a Creative Commons Attribution 4.0 International License, which permits use, sharing, adaptation, distribution and reproduction in any medium or format, as long as you give appropriate credit to the original author(s) and the source, provide a link to the Creative Commons licence, and indicate if changes were made. The images or other third party material in this article are included in the article's Creative Commons licence, unless indicated otherwise in a credit line to the material. If material is not included in the article's Creative Commons licence and your intended use is not permitted by statutory regulation or exceeds the permitted use, you will need to obtain permission directly from the copyright holder. To view a copy of this licence, visit http://creativecommons.org/licenses/by/4.0/.

\section{References}

AGA [Arbeitsgruppe Artenschutzprogramm Berlin] (1984) Grundlagen für das Artenschutzprogramm Berlin. Landschaftsentwicklung Umweltforschung 23:1-3

Alberti M, Marzluff JM, Shulenberger E, Bradley G, Ryan C et al (2003) Integrating humans into ecology: opportunities and challenges for studying urban ecosystems. Bioscience 53:1169-1179

Aronson MF, Lepczyk CA, Evans KL, Goddard MA, Lerman SB et al (2017) Biodiversity in the city: key challenges for urban green space management. Front Ecol Environ 15:189-196

Auhagen A (1985) Arten- und Biotopschutzplanung für einen Ausschnitt des Spandauer Forstes in Berlin. Landschaftsentwicklung Umweltforschung 32:1-263

Auhagen A, Platen R, Sukopp H (1991) Rote Listen der gefährdeten Pflanzen und Tiere in Berlin 1990. Landschaftsentwicklung Umweltforschung S6:57-88

Auhagen A, Sukopp H (1983) Ziel, Begründungen und Methoden des Naturschutzes im Rahmen der Stadtentwicklungspolitik von Berlin. Natur Landschaft 58:9-15

Blume HP, Sukopp H (1976) Ökologische Bedeutung anthropogener Bodenveränderungen. Schriftenr Vegetationskunde 10:5-89

Böcker R (1978) Vegetations- und Grundwasserverhältnisse im Landschaftsschutzgebiet Tegeler Fließtal (Berlin West). Verhandlungen Botanischer Verein Provinz Brandenburg 114:1-164

Böcker R, Sukopp H, Blume HP, Grenzius R, Horbert M et al (1985) Ökologische Karten Berlins. Beispiel Tegel und Tegeler See. In: Hochmeister B, Pachur HJ, Pape C, Reindke G (eds) Berlin Beiträge zur Geographie eines Großstadtraumes. Festschrift zum 45. Deutschen Geographentag in Berlin Reimer Verlag, Berlin, pp 29-72

Bornkamm R, Lee JA, Seaward MR (eds.) (1982) Urban ecology. Blackwell Scientific, Hoboken

Boyden S, Millar S, Newcombe K, O'Neill B (1981) The Ecology of a City and its People: the case of Hong Kong. Australian National University Press, Canberra

Brande A, Böcker R, Graf A (1990) Changes of flora, vegetation and urban biotopes in Berlin (West). In: Sukopp H, Hejný S, Kowarik I (eds) Urban ecology: plants and plant communities in urban environments. SPB Academic Publishing, The Hague, pp 155-165

Dettmar J (1992) Industrietypische Flora und Vegetation im Ruhrgebiet. Dissertationes Botanicae 191:1-397

Douglas I, Goode D, Houck M, Maddox D (eds; 2010) Handbook of Urban Ecology. Routledge, London

Ellis EC (2015) Ecology in an anthropogenic biosphere. Ecol Monogr 85: 287-331

Forman RT (2014) Urban ecology: science of cities. Cambridge University Press, Cambridge

Gilbert OL (1989) The Ecology of Urban Habitats. Chapman and Hall, London

Graf A (1986) Flora und Vegetation der Friedhöfe in Berlin (West). Verh Berl Bot Ver 5:1-211

Grimm NB, Faeth SH, Golubiewski NE, Redman CL, Wu J et al (2008) Global change and the ecology of cities. Science 319(5864):756-760 
Hassemer V (1995) Politikberatung zum Naturschutz in Berlin. Schriftenreihe für Vegetationskunde (Festschrift Sukopp) 27:21-25

Jalas J (1955) Hemerobe und hemerochore Pflanzenarten. Ein terminologischer Reformversuch. Acta Societas Flora Fauna Fennica 72:1-15

Kavtaradze DN (1995) The smile behind the Wall - the smile of urban ecology. Schriftenreihe für Vegetationskunde (Festschrift Sukopp) 27:27-29

Klausnitzer B (1987) Ökologie der Großstadtfauna. Fischer, Jena

Kohler A, Sukopp H (1964) Über die Gehölzentwicklung auf Berliner Trümmerstandorten. Berichte Deutsche Botanische Gesellschaft 76: 389-406

Korneck D, Sukopp H (1988) Rote Liste der in der Bundesrepublik Deutschland ausgestorbenen, verschollenen und gefährdeten Farnund Blütenpflanzen und ihre Auswertung für den Arten-und Biotopschutz. Schriftenreihe für Vegetationskunde 19:1-210

Kowarik I (1988) Zum Einfluss des Menschen auf Flora und Vegetation. Theoretische Konzepte und ein Quantifizierungsansatz am Beispiel von Berlin (West). Landschaftsentwicklung Umweltforschung 56: $1-280$

Kowarik I (1990) Some responses of flora and vegetation to urbanization in central Europe. In: Sukopp H, Hejný S, Kowarik I (eds) Urban ecology: plants and plant communities in urban environments. SPB Academic Publishing, The Hague, pp 45-74

Kowarik I (2019) The "Green Belt Berlin": Establishing a greenway where the Berlin Wall once stood by integrating ecological, social and cultural approaches. Landscape Urban Planning 184:12-22

Kowarik I, Starfinger U, Trepl L (eds; 1995) Dynamik und Konstanz. Zum 65. Geburtstag von Herbert Sukopp. Dynamik und Konstanz. Festschrift für Herbert Sukopp. Schriftenreihe für Vegetationskunde 27:1-489

Krausch HD, Sukopp H (2010) Die Geschichte der geobotanischen Forschung in Berlin und Brandenburg. Verhandlungen des Botanischen Verins von Berlins und Brandenburg. Beiheft 6:5-155

Kunick W (1974) Veränderungen von Flora und Vegetation einer Großstadt, dargestellt am Beispiel von Berlin (West). Dissertation, Technische Universität Berlin, Berlin

Kunick W (1982) Zonierung des Stadtgebietes von Berlin (West)Ergebnisse floristischer Untersuchungen. Landschaftsentwicklung Umweltforschung 14:1-164

Lachmund J (2013) Greening Berlin: The co-production of science, politics, and urban nature. MIT Press, Cambridge

Langer A (1994) Flora und Vegetation städtischer Straßen am Beispiel Berlin. Docotral thesis, Technische Universität Berlin, Berlin

Laurie IC (ed) (1979) Nature in cities. Wiley, Chichester

Lawton P, Till KE, Jasper S, Vasudevan A, Dümpelmann S et al (2019) Natura Urbana: The Brachen of Berlin. The AAG Review of Books 7:214-227

Lohmeyer W, Sukopp H (1992) Agriophyten in der Vegetation Mitteleuropas. Schriftenreihe Vegetationskunde 25:1185

Marzluff J, Shulenberger E, Endlicher W, Alberti M, Bradley G et al ((eds) (2008) Urban Ecology. An International Perspective on the Interaction between Humans and Nature. Springer, New York

Maubach C (1995) Verzeichnis der Schriften von Herbert Sukopp 19551994. Schriftenreihe für Vegetationskunde (Festschrift Sukopp) 27: 467-489

Maurer U (2002) Pflanzenverwendung und Pflanzenbestand in den Wohnsiedlungen der 1920er und 1930er Jahre in Berlin-ein Beitrag zur historischen Pflanzenverwendung. Dissertationes Botanicae 335:1-221

McDonnell MJ (2011) The history of urban ecology: An ecologist's perspective. In: Niemelä J, Breuste JH, Elmqvist T, Guntenspergen G, James $P$ et al (eds) Urban Ecology: Patterns, Processes and Applications. Oxford University Press, Oxford, pp 5-13
McDonnell MJ, Hahs AK (2013) The future of urban biodiversity research: moving beyond the 'low-hanging fruit.' Urban Ecosyst 16: 397-409

McDonnell MJ, Pickett ST (1990) Ecosystem structure and function along urban-rural gradients: an unexploited opportunity for ecology. Ecology 71:1232-1237

McPhearson T, Pickett ST, Grimm NB, Niemelä J, Alberti M et al (2016) Advancing urban ecology toward a science of cities. Bioscience 66: $198-212$

Müller N (1988) Südbayerische Parkrasen: Soziologie und Dynamik bei unterschiedlicher Pflege. Dissertationes Botanicae 123, 1-176

Nath M (1990) Historische Pflanzenverwendung in Landschaftsgärten. Wernersche Verlagsgesellschaft, Worms

Nilon CH, Aronson MF, Cilliers SS, Dobbs C, Frazee LJ et al (2017) Planning for the future of urban biodiversity: a global review of cityscale initiatives. Bioscience 67(4):332-342

Parris KM, Amati M, Bekessy SA, Dagenais D, Fryd O, Hahs AK ... Williams NSG (2018) The seven lamps of planning for biodiversity in the city. Cities 83:44-53

Peschel T (2000) Vegetationskundliche Untersuchungen der Wiesen-und Rasengesellschaften historischer Gärten in Potsdam. Ibidem-Verlag, Hannover

Pickett ST, Cadenasso ML, Childers DL, McDonnell MJ, Zhou W (2016) Evolution and future of urban ecological science: ecology in, of, and for the city. Ecosyst Health Sustain 2(7):e01229

Planchuelo G, von der Lippe M, Kowarik I (2019) Untangling the role of urban ecosystems as habitats for endangered plant species. Landscape Urban Planning 189:320-334

Pobloth S (2008) Die Entwicklung der Landschaftsplanung in Berlin im Zeitraum 1979 bis 2004 unter besonderer Berücksichtigung der Stadtökologie. Mensch und Buch, Berlin

Qiu L, Gao T, Gunnarsson A, Hammer M, von Bothmer R (2010) A methodological study of biotope mapping in nature conservation. Urban Forestry Urban Greening 9:161-166

Röhricht W (2003) Zur Pflanzenwelt der Neubaugebiete Ost-Berlins. Dissertationes Botanicae 376:1-382

Schulte W, Sukopp H, Werner P (1993) Flächendeckende Biotopkartierung im besiedelten Bereich als Grundlage einer am Naturschutz orientierten Planung. Natur Landschaft 68:491-526

Seidling W (1990) Räumliche und zeitliche Differenzierungen der Krautschicht bodensaurer Kiefern-Traubeneichenwälder in Berlin (West). Berichte Forschungszentrum Waldökosysteme. Reihe A 61:1-261

Seitz B, Ristow M, Meißner J, Machatzi B, Sukopp H (2018) Rote Liste und Gesamtartenliste der etablierten Farn-und Blütenpflanzen von Berlin. Universitätsverlag der TU Berlin, Berlin

Shwartz A, Turbe A, Julliard R, Simon L, Prevot AC (2014) Outstanding challenges for urban conservation research and action. Glob Environ Change 28:39-49

Stearns F, Montag T (1975) The urban ecosystem: a holistic approach. Dowden, Hutchinson \& Ross, New York

Sukopp H (1959) /60) Vergleichende Untersuchungen der Vegetation Berliner Moore unter besonderer Berücksichtigung der anthropogenen Veränderungen. Bot Jahrb 79:36-191

Sukopp H (1962) Neophyten in natürlichen Pflanzengesellschaften Mitteleuropas. Ber Deutsch Bot Ges 75:193-205

Sukopp H (1966) Verluste der Berliner Flora während der letzten hundert Jahre. Sitzungsberichte der Gesellschaft Naturforschender Freunde Berlin (NF) 6:126-136

Sukopp H (1969) Der Einfluss des Menschen auf die Vegetation. Vegetatio 17:360-371

Sukopp H (1971) Beiträge zur Ökologie von Chenopodium botrys L. 1. Verbreitung und Vergesellschaftung. Verh Bot Verein Provinz Brandenburg 108:3-25

Sukopp H (1972) Wandel von Flora und Vegetation in Mitteleuropa unter dem Einfluß des Menschen. Ber Landwirtsch 50:112-139 
Sukopp H (1973) Die Großstadt als Gegenstand ökologischer Forschung. Schr. Ver. Verbreitung naturwiss. Kenntnisse in Wien 113:90-140

Sukopp H (1974) „Rote Liste“ der in der Bundesrepublik Deutschland gefährdeten Arten von Farn- und Blütenpflanzen (1. Fassung). Natur und Landschaft 49:315-322

Sukopp H (ed; 1990) Stadtökologie. Das Beispiel Berlin. D. Reimer Verlag, Berlin

Sukopp H (1998) Urban ecology — scientific and practical aspects. In: Breuste J, Feldmann H, Uhlmann O (eds) Urban ecology. Springer, Berlin, pp 3-16

Sukopp H (2002) On the early history of urban ecology in Europe. Preslia 74:373-393 (reprinted in Marzluffet al. 2008)

Sukopp H (2004) Human-caused impact on preserved vegetation. Landsc Urban Plan 68:347-355

Sukopp H, Blume HP, Elvers H, Horbert M (eds; 1980) Beiträge zur Stadtökologie von Berlin (West). Landschaftsökologie und Umweltforschung 3:1-225

Sukopp H, Blume HP, Kunick W (1979a) The soil, flora, and vegetation of Berlin's waste lands. In: Laurie IC (ed) Nature in cities. Wiley, Chichester, pp 115-132

Sukopp H, Kunick W, Schneider C (1979b) Biotopkartierung in der Stadt. Natur Landschaft 54(3):66-68

Sukopp H, Böcker R, Brande A (2015) Die Kaukasische Flügelnuss in und um Berlin. Verh Bot Ver Berlin Brandenburg 148:31-81

Sukopp H, Elvers H (1982) Rote Liste der gefährdeten Pflanzen und Tiere in Berlin (West). Landschaftsentwicklung Umweltforschung 11:1-374
Sukopp H, Hejný S, Kowarik I (eds; 1990) Urban ecology: plants and plant communities in urban environments. SPB Academic Publishing, The Hague

Sukopp H, Markstein B (1989) Changes of the reed beds along the Berlin Havel, 1962-1987. Aquat Bot 35:27-39

Sukopp H, Numata M, Huber A (eds; 1995) Urban ecology as the basis of urban planning. SPB Academemic Publishing, The Hague

Sukopp H, Weiler S (1988) Biotope mapping and nature conservation strategies in urban areas of the Federal Republic of Germany. Landsc Urban Plan 15:39-58

Sukopp H, Werner P (1983) Urban environments and vegetation. In: Holzner W, Werger MJA, lkusima I (eds) Man's impact on vegetation. Dr W. Junk Publishers, The Hague, pp 247-260

Sukopp H, Wittig R (1993) Stadtökologie. Gustav Fischer, Stuttgart

Sukopp H, Wittig R (1998) Stadtökologie, 2nd edition. Gustav Fischer, Stuttgart

Thierfelder H, Kabisch N (2016) Viewpoint Berlin: Strategic urban development in Berlin-Challenges for future urban green space development. Environ Sci Policy 62:120-122

Trepl L (1984) Über Impatiens parviflora DC. als Agriophyt in Mitteleuropa. Dissertationes Botanicae 73:1-400

Wu J (2014) Urban ecology and sustainability: The state-of-the-science and future directions. Landsc Urban Plan 125:209-221

Wu J, Xiang WN, Zhao J (2014) Urban ecology in China: Historical developments and future directions. Landsc Urban Plan 125:222-233

Zerbe S, Maurer U, Schmitz S, Sukopp H (2003) Biodiversity in Berlin and its potential for nature conservation. Landsc Urban Plan 62: $139-148$ 